meanwhile to engender sufficient support for a more extensive and detailed study in the future.

The Commission members would welcome ideas and suggestions on the Middle East water issues from anyone interested. These should be sent either to the Chairman (undersigned) or to any other member of the Commission.

\section{REFERENCE}

BisWAS, ASIT K. (1994). International Waters of the Middle East: From Euphrates-Tigris to Nile. Oxford University Press, Oxford \& New Delhi: xvii +221 pp., illustr.
Asit K. Biswas, Chairman

IWRA Committee on International Waters

76 Woodstock Close

Oxford $O X 28 D D$

England, $U K$,

\&

AARON T. WOLF

Department of Geography

University of Alabama

Tuscaloosa

Alabama 35487, USA

\title{
Regina Amendments to Ramsar Convention on Wetlands Come Into Force
}

$\mathrm{T}^{\mathrm{s}}$ he Convention on Wetlands of International Importance, especially as Waterfowl Habitat, adopted in Ramsar, Iran, in 1971, was the first of the modern global Nature treaties and remains the only such agreement to cover the conservation of a particular habitat-type. The text of the treaty contained deficiencies, however, which long impeded its proper functioning: for instance, no provisions were made for financing of the Convention or a secretariat, for decision-making authority, for languages other than English, or for any mechanism for amendment. In consequence, the Convention's membership grew slowly for several years, and its activities were limited, whilst the legal basis was being proposed for revision of the treaty.

At the Third Meeting of the Conference of the Contracting Parties, held in Regina, Canada, in 1987, the member States adopted amendments to the Convention which were intended to remedy these weaknesses in the original text. Although these 'Regina amendments', establishing the Conference of the Contracting Parties as the decision-

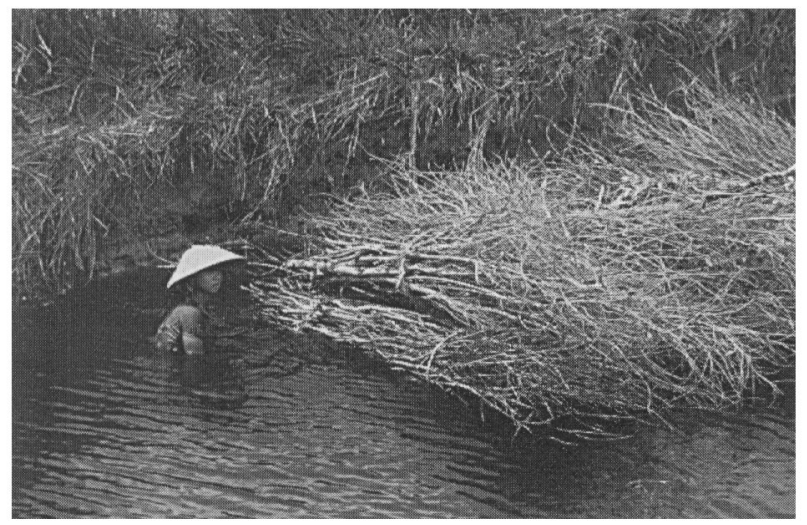

FIG. 1. A wetland activity: collecting Melalenca wood in the Mekong Delta, Viet Nam. Photo: H. Lethier/Ramsar Bureau.

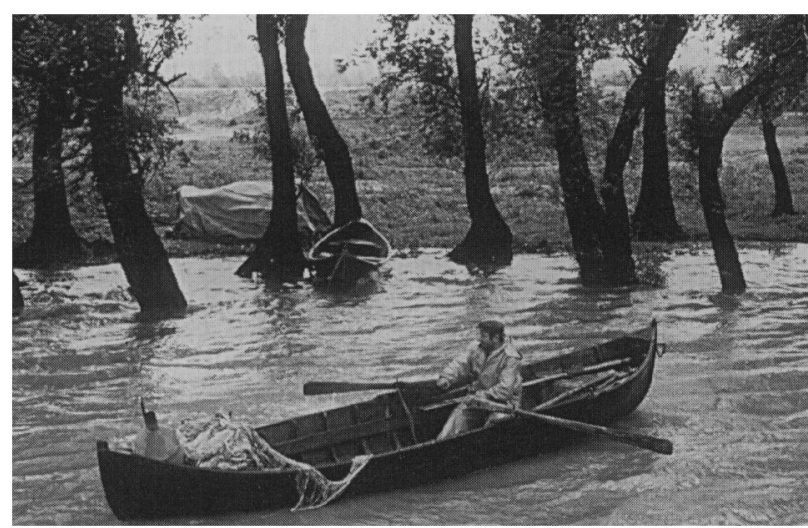

FIG. 2. Another wetland activity portrayed: fisherman in the Danube Delta, Romania, where fishing is an important aspect of the local economy. Photo: Elizabeth Hopkins/IUCN.

making authority and providing a stable financial regime for the Convention and the work of its secretariat, have been applied provisionally since 1987 , they required formal govermental acceptance by two-thirds of the States which were Contracting Parties at that time. Figs 1 and 2 illustrate two of the innumerable wetland activities of which the sustainability may be dependent on the Ramsar Convention.

It is with great satisfaction that the Ramsar Convention Bureau announces that, with the recent action by Denmark, the Regina amendments came officially into force on 1 May 1994.

Mireille Katz, Communication Officer

Convention on Wetlands of International Importance Especially as Wildfowl Habitat

Rue Mauverney 28

CH-I196 Gland

\section{Eco-clubs: A Role for Children in Environmental Conservation}

$\mathrm{I}_{\mathrm{a}}^{\mathrm{t}}$ is often said that children 'own' the future. If this is accepted, then there should be mechanisms not just to permit, but to encourage and mobilize, the efforts of children in shaping their futures.

One such mechanism has recently come into being. On 5 June 1993 - World Environment Day - the Government of India announced an initiative to provide a role for schoolchildren in managing, preserving, and conserving, their environments. The student response in schools that I visited in Bangalore and Mysore in December, 1993, was unanimously enthusiastic. Extension of this Indian initiative to other parts of the world could provide a global basis for much-improved attention to long-term human and environmental interests.

The full text of the Indian 'Eco-club' initiative is given above on pages 69-70, following a Foreword by the Indian Minister of Environment. *

JOHN R. VALLENTYNE, alias 'Johnny Biosphere' 36 Longwood Road North

Hamilton

Ontario L8S 3V4

Canada.

* H.E. Kamal Nath, who has sanctioned our publication of that account. - Ed. 